\title{
FOREST COVERAGE AND STREAMFLOW OF WATERSHEDS IN THE TROPICAL ATLANTIC RAINFOREST ${ }^{1}$
}

\author{
Natalia Gomes de Souza Mendes ${ }^{2 *}$, Roberto Avelino Cecílio ${ }^{3}$ and Sidney Sara Zanetti ${ }^{4}$
}

\footnotetext{
${ }^{1}$ Received on 19.06.2017 accepted for publication on 05.04.2018.

${ }^{2}$ Universidade Federal do Espírito Santo, Mestre em Ciências Florestais, Jeronimo Monteiro, ES - Brasil. E-mail:<n.gsmendes@gmail.com>.

${ }^{3}$ Universidade Federal do Espírito Santo, Departamento de Engenharia Florestal, Jeronimo Monteiro, ES - Brasil. E-mail: <roberto.cecilio@ufes.br>.

${ }^{4}$ Universidade Federal do Espírito Santo, Departamento de Ciências Florestais e da Madeira, Jeronimo Monteiro, ES - Brasil. E-mail: <sidney.zanetti@ufes.br>.

*Corresponding author.
}

\begin{abstract}
The present study analyzed the average and minimum streamflow behavior of 11 watersheds located in the Atlantic Forest Biome, relating them to the changes in forest cover. The average minimum flow with seven days of duration $\left(\mathrm{Q}_{7}\right)$, the average annual flow $\left(\mathrm{Q}_{\mathrm{ave}}\right)$, the total annual precipitation $\left(\mathrm{P}_{\mathrm{a}}\right)$ and the percentage of forest cover (FC) for each watershed were determined. The joint correlation between the $\mathrm{FC}$ and the $\mathrm{P}_{\mathrm{a}}$ with the flow for each watershed were analyzed by adjusting multiple linear regression equations. The partial correlation coefficient was also used to analyze whether the variation in the FC influenced the water flow when the effects of $\mathrm{P}_{\mathrm{a}}$ are fixed. This study allowed us to identify significant associations between FC and $P_{a}$ with $Q_{7}$ or $Q_{a v e}$ in only two of the watersheds. Disregarding the effects of $P_{a}$, the increase in the $\mathrm{FC}$ tended to result in a reduction in the $\mathrm{Q}_{\mathrm{ave}}$, and in turn increased the $\mathrm{Q}_{7}$ in these two watersheds.
\end{abstract}

Keywords: Water availability, Watershed management, Forest hydrology.

\section{COBERTURA FLORESTAL E VAZÕES DE BACIAS HIDROGRAFICAS DA MATA ATLÂNTICA}

\begin{abstract}
RESUMO - O presente trabalho analisou o comportamento das vazões médias e mínimas de cursos d'água de 11 bacias hidrográficas localizadas no Bioma Mata Atlântica, relacionando-as às mudanças ocorridas na cobertura florestal. Determinaram-se, para cada bacia, a vazão mínima média com sete dias de duração $\left(Q_{7}\right)$, a vazão média anual ( $Q_{\text {ave }}$ ), a precipitação total anual $(P a)$ e o percentual de cobertura florestal (FC). Para cada bacia, a correlação conjunta da FC e Pa com as vazões foi analisada por meio do ajuste de equações de regressão linear múltipla. Também foi utilizado o coeficiente de correlação parcial para analisar se a variação do FC exerceu influência nas vazões, quando os efeitos da Pa são fixados. O estudo permitiu a identificação de associações significativas entre $\mathrm{FC} \mathrm{e} \mathrm{Pa} \mathrm{com} Q_{7}$ ou $Q_{\text {ave }}$ em apenas duas bacias. Descontados os efeitos da Pa, o incremento da FC tendeu a provocar redução da $Q_{\text {ave }}$,endo como contrapartida o aumento da $Q_{7}$ nestas duas bacias.
\end{abstract}

Palavras-Chave: Disponibilidade hídrica, Manejo de bacias hidrográficas, Hidrologia florestal 


\section{INTRODUCTION}

In addition to being a basic resource essential for life, water is also central to almost all human activities. Due to its importance, water resources are considered as a common good which must be managed in an integrated way, guaranteeing optimization of its use. The conservation of water resources is a matter of concern to mankind and has become a priority given the scarcity of water in several regions of the world (Hoekstra et al., 2012; Schewe et al., 2014), as well as to the increasing conflicts related to its use (Böhmelt et al., 2014; Gleick, 2014).

The water availability of watersheds in terms of quantity and quality result from complex natural control mechanisms developed throughout evolutionary processes of the landscape, which constitute the environmental services provided by the ecosystem (Rosa et al., 2014, 2016). Some forest functions in the hydrological watershed regime are based on myths and traditions, without any support of scientific data (Bacellar, 2005). The public perception that forests, under all circumstances, regulate water regimes, increase streamflow, and guarantee the water supply has long been questioned by the scientific community, whom in many cases suggest a more complex view of forests in relation to the quantity of water resources (Calder, 2007).

Water flow is the result of the integration of hydrological and anthropic components of the watersheds, and its knowledge is reflected in water availability. Therefore, studies that seek to better understand the relationship between changes in forest ecosystems and the streamflow regime are of great importance for understanding the real situation of these resources in order to support watershed management (Bosch and Hewlett, 1982; Hornbeck et al., 1993; Farley et al., 2005; Brown et al., 2013).

Inserted in the Atlantic Forest Biome, the Itapemirim river basin (IRB), as well as most of the watersheds of the State of Espírito Santo in Brazil, has been the subject of few studies that relate forest cover to streamflow behavior. In recent years, the streamflow reduction of Espírito Santo rivers has been evidenced, especially the minimum streamflow, which has motivated an incentive for forest coverage restoration projects. It is important that public policy proposals related to reforestation be preceded by knowledge of the effective impacts that forests have on water resources. Such impacts are often positive from the point of view of water quality (Ferraz et al., 2013; Brito et al., 2016); however, they vary in relation to streamflow behavior (Bosch and Hewlett, 1982).

Given the above, the present study had the objective of analyzing the behavior of average and minimum flow of the IRB watercourses, relating them to changes that have occurred in forest coverage.

\section{MATERIALAND METHODS}

The Itapemirim river basin (IRB) is located in the southern region of the State of Espírito Santo (Figure 1), with a total area of approximately $5,920 \mathrm{~km}^{2}$. According to the Köppen classification, the predominant climatic types are "Cwa" - Humid Subtropical climate with dry winter and hot summer, and " $C w b$ " - Humid Subtropical climate with a dry winter and temperate summer (Alvares et al., 2013). The vegetation is within the domains of the Atlantic Forest Biome, according to the following formations: Ombrophilous Dense Forest (low slope, montane, and high montane); and Semideciduous Seasonal Forest (low lands and low slope) (IBGE, 2012).

\subsection{Forest cover mapping}

Images with a spatial resolution of 30 meters from sensors on board the Landsat 5 sensor TM satellite were used (Thematic Mapper) for mapping the forest coverage in the IRB, covering the study area at the orbit points 216/74 and 216/75 (WGS 84 ellipsoid). These images covered the period from 1985 to 2011 , at twoyear intervals. Based on the quantification of forest percentages obtained for these periods by supervised classification, these images were subsequently used as means for a seven-year base adoption for analyzing the forest coverage (1987, 1991, 1995, 1999, 2003, 2007 and 2011).

Registration, histogram enhancement and filtering procedures of the satellite sensor images were performed in order to obtain improvements in the visual and geometric quality of satellite sensor images. Supervised classification was applied to identify the forest cover of the entire study area. Samples for the supervised classification training included vegetation of native forest trees at any regeneration stage. These samples

Revista Árvore. 2018;42(2):e420204

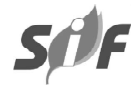



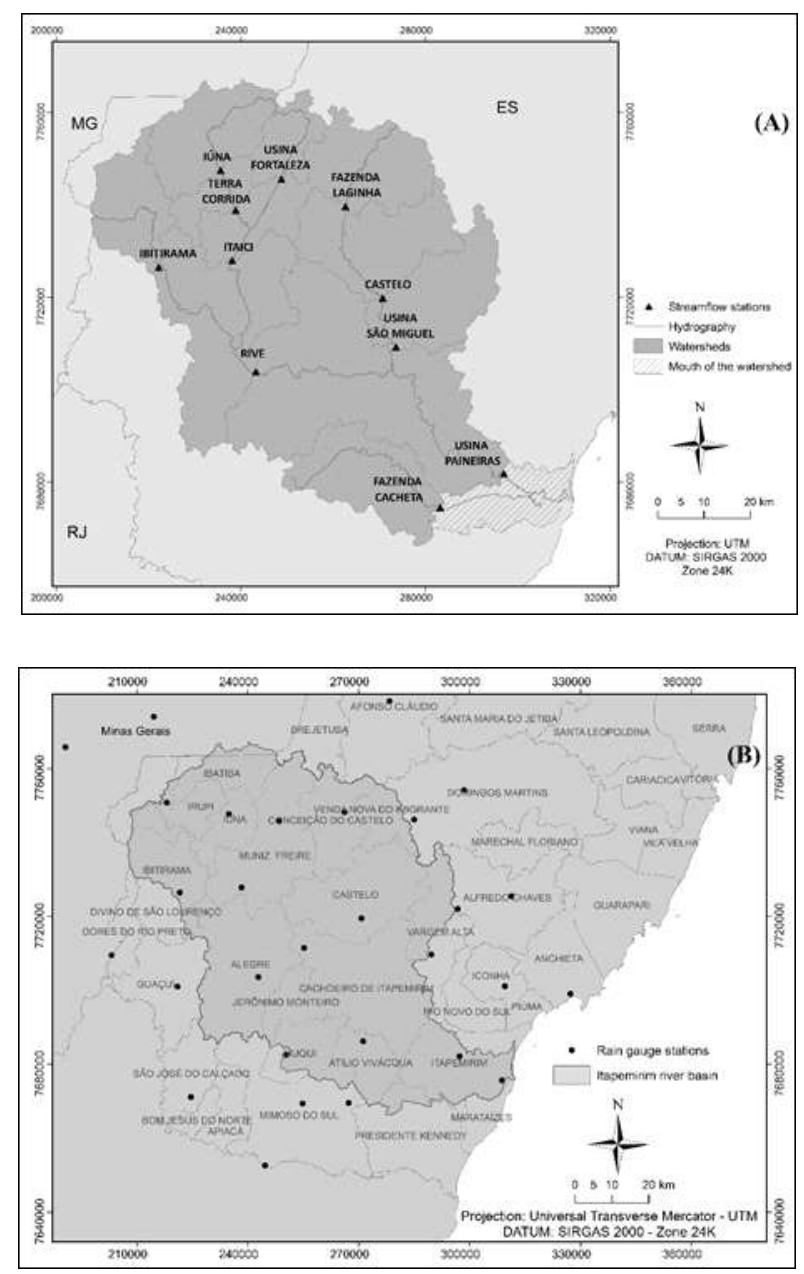

Figure 1 - Location of streamflow stations, respective watersheds (A), and rain gauge stations (B) in the Itapemirim river basin.

Figura 1 - Localização, na bacia hidrográfica do rio Itapemirim, das estações fluviométricas e suas respectivas subbacias (A) e das estações pluviométricas utilizadas no estudo (B).

were compared with the land use and occupation map for 2007, which was prepared based on the manual photointerpretation of the rectified orthophotomosaic of the State Institute of Environment and Water Resources (IEMA, 2008), with a spatial resolution of one meter in order to confirm whether the class sampled in this study was actually native vegetation. An average of 62 vegetation areas were sampled for each satellite image of each analyzed year. Based on the spectral signatures of the samples extracted from the Landsat 5 images, the forest coverage mapping for the whole IRB was performed using the Maximum Likelihood algorithm for the supervised classification, with an acceptance threshold of $99 \%$. The Majority Filter was applied to each forest coverage map, and an analysis of the eight neighbors for each isolated pixel to be filtered was adopted as filter criteria. The accuracy of the vegetation maps was subsequently performed using the Kappa index (equation 1) (Foody, 2004). The forest areas present in each watershed were then determined after these procedures, also expressed as relative terms (watershed percentages):

$$
\mathrm{K}=100 \cdot \frac{\mathrm{Po}-\mathrm{Pc}}{1-\mathrm{Pc}}
$$

in which:

$$
\begin{aligned}
& \mathrm{Po}=\text { proportion of agreement observed; and } \\
& \mathrm{Pc}=\text { proportion of disagreement observed }
\end{aligned}
$$

\subsection{Hydrological data}

River flow data were obtained from the Hydrological Information System of the National Water Agency (Hidroweb), corresponding to the daily historical streamflow series of 11 stations situated in the IRB (Figure 1A and Table 1), for the period from 1985 to 2011. The IRB was subdivided according to the contribution areas (watersheds) of each of these 11 stations in order to analyze changes in land use and its relationship with the streamflow.

For each of the 11 stations located in the watershed, the average minimum flow with seven days of duration $\left(\mathrm{Q}_{7}\right)$ and the average annual flow $\left(\mathrm{Q}_{\mathrm{ave}}\right)$ were obtained. These streamflows were determined for each base year according to the daily data from the three previous years to each base year, also including the streamflow of these years. In order to verify the occurrence of significant changes throughout the streamflow series, stationarity was evaluated using the F-test and Student's t-test at $1 \%$ probability, with stationarity being verified for all of them.

Precipitation data from 1985 to 2011 were obtained from 29 rain gauge stations (Figure 1B) also from Hidroweb. Some of these stations are located in the vicinity of the basin, and were used with the objective of minimizing the edge effect in the interpolation process. The total annual precipitation $(\mathrm{Pa})$ was estimated for each watershed according to the rainfall spacing of 
Table 1 - Streamflow stations and watersheds of the Itapemirim basin.

Tabela 1 - Estações fluviométricas e sub-bacias hidrográficas da Bacia do Itapemirim.

\begin{tabular}{|c|c|c|c|}
\hline ANA Code & Station (Watershed) & River & $\operatorname{Area}\left(\mathrm{Km}^{2}\right)$ \\
\hline 57490000 & Castelo (CAS) & Rio Castelo & 975 \\
\hline 57650000 & Fazenda Cacheta (FCA) & Rio Muqui do Norte & 481 \\
\hline 57476500 & Fazenda Laginha (FLA) & Rio Castelo & 436 \\
\hline 57420000 & Ibitirama (IBI) & Rio Braço Norte Direito & 342 \\
\hline 57400000 & Itaici (ITA) & Rio Braço Norte Esquerdo & 1045 \\
\hline 57360000 & Iúna (IUN) & Rio Pardo & 432 \\
\hline 57450000 & Rive (RIV) & Rio Itapemirim & 2218 \\
\hline 57370000 & Terra Corrida Montante (TCM) & Rio Pardo & 587 \\
\hline 57350000 & Usina Fortaleza (UFO) & Rio Braço Norte Esquerdo & 196 \\
\hline 57580000 & Usina Paineiras (UPA) & Rio Itapemirim & 5168 \\
\hline 57550000 & Usina São Miguel (USM) & Rio Castelo & 1459 \\
\hline
\end{tabular}

the 29 stations, based on the Inverse Distance to Square method indicated for the rainfall spatialization of the same period in the IRB (Mendes, 2016). In order to verify the occurrence of significant changes throughout the Pa series, stationarity was also evaluated using the F-test and the Student's t-test at $1 \%$ probability, with stationarity being verified for all of them.

\subsection{Statistical analysis}

The joint correlation of all variables (forest, annual rainfall and streamflow) for each studied watershed was analyzed by the adjustment of multiple linear regression equations using the Student's t-test at 5\% of probability to evaluate the significance of each parameter in the equations.

The partial correlation coefficient is used to evidence the linear correlation between any two variables when the effects of other variables are fixed, and was also used in this case. Thus, with the use of partial correlation, we sought to analyze whether the variation in forest coverage percentage influenced the hydrological regime of the IRB watersheds when the effects of annual rainfall (Pa) on streamflow were fixed. The F-test at a 5\% probability was applied to verify the significance of the obtained partial correlation coefficients.

\section{RESULTS}

Regarding the accuracy evaluation of forest coverage maps, Kappa Index values for all the mapping years were superior to $96 \%$, denoting excellent performance. Table 2 shows the values for $\mathrm{FC}, \mathrm{Q}_{\mathrm{ave}}, \mathrm{Q}_{7}$ and $\mathrm{Pa}$ for each watershed at each of the base years considered in the present study.

Revista Árvore. 2018;42(2):e420204
The partial correlation between the forest coverage percentage and the streamflow by fixing the Pa effects are presented in Table 3 . Table 4 presents the multiple linear regression equations for the association of streamflow with the forest coverage (FC) percentage and $\mathrm{Pa}$ for watersheds where such correlation was statistically significant.

\section{DISCUSSION}

\subsection{Forest cover mapping}

For the first year of analysis, $31.3 \%$ forest coverage was found in the IRB $\left(1,767.71 \mathrm{~km}^{2}\right)$, while for 2011 it was $28.7 \%\left(1,621.17 \mathrm{~km}^{2}\right)$. A total corresponding to the suppression of $2.6 \%$ of the forest areas in the basin between the first and last years of evaluation was observed. Another study that mapped the native forest areas of the IRB ((Coutinho and Sampaio, 2007) over a period of 29 years (1977 to 2006) also found a tendency of forest coverage reduction. In the cited study, the forest area percentages were $38.4 \%$ in 1977 and $30.4 \%$ in 2006. The effective reduction of forests occurred in the lower areas of the IRB: a reduction from $24 \%$ to $21 \%$ in the FCA watershed; and a reduction from $26 \%$ to $25 \%$ in the UPA watershed. In relation to the UPA watershed, the reduction was located in the lower altitude contribution area, located downstream of the RIV and USM stations. An increase in the forest coverage was observed in the watershed areas upstream of the RIV and USM stations, with emphasis on the FLA watershed, in which the forest area increased from 37 to $47 \%$.

For the evaluated period, the average forest coverage percentage in the IRB was $25.2 \%$; a relevant value when 
Forest coverage and streamflow of...

Table 2 - Percentage of forest coverage (FC), average annual flow $\left(\mathrm{Q}_{\mathrm{ave}}\right)$, seven days duration minimum flow $\left(\mathrm{Q}_{7}\right)$ and annual rainfall depth $(\mathrm{Pa})$ of each watershed in the Itapemirim river basin at each period of evaluation.

Tabela 2 - Percentual de cobertura florestal $(F C)$, vazão média $\left(Q_{a v}\right)$, vazão mínima $\left(Q_{7}\right)$ e precipitação média anual (Pa) em cada sub-bacia hidrográfica da Bacia do rio Itapemirim nos diferentes anos avaliados.

\begin{tabular}{|c|c|c|c|c|c|c|c|c|}
\hline Station & Variable & - & & 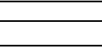 & Base years & & & $\overline{-}$ \\
\hline & & 1987 & 1991 & 1995 & 1999 & 2003 & 2007 & 2011 \\
\hline \multirow[t]{4}{*}{ Castelo } & FC (\%) & 32 & 36 & 34 & 35 & 35 & 30 & 37 \\
\hline & $\mathrm{Q}_{7}\left(\mathrm{~m}^{3} \mathrm{~s}^{-1}\right)$ & 4.1 & 7.6 & 2.9 & 2.4 & 2.1 & 2.0 & 2.7 \\
\hline & $\mathrm{Q}_{\mathrm{ave}}\left(\mathrm{m}^{3} \mathrm{~s}^{-1}\right)$ & 18.6 & 12.3 & 13.7 & 13.0 & 12.2 & 19.8 & 18.6 \\
\hline & $\mathrm{Pa}(\mathrm{mm})$ & 1525 & 1354 & 1249 & 1363 & 1268 & 1510 & 1540 \\
\hline \multirow[t]{4}{*}{ Fazenda Cacheta } & FC (\%) & 24 & 36 & 23 & 20 & 21 & 18 & 21 \\
\hline & $\mathrm{Q}_{7}\left(\mathrm{~m}^{3} \mathrm{~s}^{-1}\right)$ & 1.1 & 1.6 & 0.3 & 0.8 & 1.1 & 1.3 & 2.0 \\
\hline & $\mathrm{Q}_{\mathrm{ave}}\left(\mathrm{m}^{3} \mathrm{~s}^{-1}\right)$ & 6.6 & 4.0 & 5.2 & 6.8 & 4.1 & 7.4 & 7.8 \\
\hline & $\mathrm{Pa}(\mathrm{mm})$ & 1275 & 1202 & 1239 & 1211 & 1186 & 1534 & 1433 \\
\hline \multirow[t]{4}{*}{ Fazenda Laginha } & FC (\%) & 37 & 40 & 42 & 43 & 46 & 39 & 47 \\
\hline & $\mathrm{Q}_{7}\left(\mathrm{~m}^{3} \mathrm{~s}^{-1}\right)$ & 2.4 & 2.7 & 1.2 & 1.1 & 0.8 & 1.3 & 1.7 \\
\hline & $Q_{\text {ave }}\left(\mathrm{m}^{3} \mathrm{~s}^{-1}\right)$ & 8.1 & 6.7 & 7.1 & 7.4 & 6.5 & 9.1 & 7.6 \\
\hline & $\mathrm{Pa}(\mathrm{mm})$ & 1553 & 1350 & 1205 & 1356 & 1268 & 1460 & 1495 \\
\hline \multirow[t]{4}{*}{ Ibitirama } & FC (\%) & 30 & 31 & 34 & 32 & 36 & 33 & 36 \\
\hline & $\mathrm{Q}_{7}\left(\mathrm{~m}^{3} \mathrm{~s}^{-1}\right)$ & 2.0 & 3.7 & 1.4 & 1.9 & 1.9 & 2.1 & 2.3 \\
\hline & $Q_{\text {ave }}\left(m^{3} \mathrm{~s}^{-1}\right)$ & 12.5 & 10.6 & 11.6 & 12.0 & 11.6 & 15.7 & 13.6 \\
\hline & $\mathrm{Pa}(\mathrm{mm})$ & 1549 & 1424 & 1311 & 1472 & 1427 & 1760 & 1723 \\
\hline \multirow[t]{4}{*}{$\overline{\text { Itaici }}$} & FC (\%) & 18 & 20 & 19 & 20 & 23 & 16 & 20 \\
\hline & $\mathrm{Q}_{7}\left(\mathrm{~m}^{3} \mathrm{~s}^{-1}\right)$ & 5.2 & 8.7 & 4.0 & 4.1 & 4.2 & 5.9 & 6.4 \\
\hline & $\mathrm{Q}_{\mathrm{ave}}\left(\mathrm{m}^{3} \mathrm{~s}^{-1}\right)$ & 22.0 & 15.0 & 18.6 & 20.0 & 17.6 & 24.9 & 20.7 \\
\hline & $\mathrm{Pa}(\mathrm{mm})$ & 1397 & 1352 & 1166 & 1453 & 1327 & 1535 & 1555 \\
\hline \multirow[t]{4}{*}{ Iúna } & FC (\%) & 12 & 14 & 12 & 15 & 19 & 12 & 12 \\
\hline & $\mathrm{Q}_{7}\left(\mathrm{~m}^{3} \mathrm{~s}^{-1}\right)$ & 3.0 & 6.1 & 1.9 & 3.2 & 2.4 & 3.5 & 4.0 \\
\hline & $\mathrm{Q}_{\mathrm{ave}}\left(\mathrm{m}^{3} \mathrm{~s}^{-1}\right)$ & 9.8 & 6.3 & 12.4 & 8.0 & 7.6 & 9.2 & 8.5 \\
\hline & $\mathrm{Pa}(\mathrm{mm})$ & 1361 & 1351 & 1167 & 1418 & 1373 & 1512 & 1552 \\
\hline \multirow[t]{4}{*}{ Rive } & FC (\%) & 19 & 23 & 19 & 20 & 21 & 17 & 20 \\
\hline & $Q_{7}\left(m^{3} s^{-1}\right)$ & 10.8 & 16.9 & 8.2 & 10.9 & 10.8 & 13.0 & 14.8 \\
\hline & $Q_{\text {ave }}\left(m^{3} \mathrm{~s}^{-1}\right)$ & 49.7 & 32.8 & 38.2 & 43.9 & 38.9 & 55.2 & 48.3 \\
\hline & $\mathrm{Pa}(\mathrm{mm})$ & 1473 & 1360 & 1248 & 1412 & 1339 & 1635 & 1635 \\
\hline \multirow[t]{4}{*}{ Terra Corrida } & FC (\%) & 13 & 16 & 14 & 16 & 19 & 13 & 14 \\
\hline & $\mathrm{Q}_{7}\left(\mathrm{~m}^{3} \mathrm{~s}^{-1}\right)$ & 3.7 & 5.0 & 2.3 & 3.5 & 3.3 & 4.1 & 5.2 \\
\hline & $\mathrm{Q}_{\mathrm{ave}}\left(\mathrm{m}^{3} \mathrm{~s}^{-1}\right)$ & 12.4 & 7.8 & 9.8 & 11.4 & 10.4 & 13.1 & 12.4 \\
\hline & $\mathrm{Pa}(\mathrm{mm})$ & 1357 & 1349 & 1172 & 1416 & 1367 & 1516 & 1554 \\
\hline \multirow[t]{4}{*}{ Usina Fortaleza } & FC (\%) & 28 & 27 & 29 & 28 & 35 & 26 & 32 \\
\hline & $\mathrm{Q}_{7}\left(\mathrm{~m}^{3} \mathrm{~s}^{-1}\right)$ & 0.9 & 1.9 & 1.6 & 0.8 & 0.7 & 0.8 & 1.1 \\
\hline & $Q_{a v e}\left(m^{3} s^{-1}\right)$ & 4.9 & 4.2 & 5.3 & 5.3 & 4.0 & 5.6 & 4.3 \\
\hline & $\mathrm{Pa}(\mathrm{mm})$ & 1437 & 1369 & 1096 & 1357 & 1295 & 1514 & 1515 \\
\hline \multirow[t]{4}{*}{ Usina Paineiras } & $\mathrm{FC}(\%)$ & 26 & 31 & 24 & 24 & 25 & 21 & 25 \\
\hline & $\mathrm{Q}_{7}\left(\mathrm{~m}^{3} \mathrm{~s}^{-1}\right)$ & 19.5 & 42.0 & 15.4 & 17.2 & 19.2 & 20.1 & 25.3 \\
\hline & $\mathrm{Q}_{\text {ave }}\left(\mathrm{m}^{3} \mathrm{~s}^{-1}\right)$ & 93.4 & 69.0 & 76.7 & 84.2 & 71.5 & 118.0 & 102.0 \\
\hline & $\mathrm{Pa}(\mathrm{mm})$ & 1480 & 1359 & 1286 & 1387 & 1296 & 1601 & 1603 \\
\hline \multirow[t]{4}{*}{$\overline{\text { Usina São Miguel }}$} & $\mathrm{FC}(\%)$ & 36 & 41 & 37 & 37 & 38 & 33 & 39 \\
\hline & $Q_{7}\left(m^{3} s^{-1}\right)$ & 6.8 & 9.3 & 7.5 & 4.8 & 3.9 & 4.8 & 6.2 \\
\hline & $\mathrm{Q}_{\mathrm{ave}}\left(\mathrm{m}^{3} \mathrm{~s}^{-1}\right)$ & 25.8 & 18.8 & 24.4 & 20.6 & 17.5 & 30.4 & 26.1 \\
\hline & $\mathrm{Pa}(\mathrm{mm})$ & 1524 & 1384 & 1307 & 1381 & 1273 & 1552 & 1571 \\
\hline
\end{tabular}

compared to only $10.4 \%$ of forest remnants of Atlantic Forest in the State of Espírito Santo (FUNDAÇÃO SOS MATAATLÂNTICA, 2015). This is due to the fact that the IRB has important protected forest remnant areas such as the Itabira Municipal Park (163.0 ha), the Pacotuba National Forest (449.4 ha), the Cafundó Natural Heritage Private Reserve (517.0 ha) and the Caparaó National Park (PARNA Caparaó) $(31,700.0 \mathrm{ha})$. 
Table 3 - Partial correlation coefficient $\left(R_{p}\right)$ between streamflow and forest coverage, maintaining the effects of annual rainfall constant for all watersheds of the present study.

Tabela 3 - Coeficientes de correlação parcial $\left(R_{p}\right)$ entre as vazões e o percentual de cobertura florestal, fixando o efeito da precipitação anual para as sub-bacias da BHRI.

\begin{tabular}{|c|c|c|c|c|}
\hline \multirow[t]{2}{*}{ Watershed } & \multicolumn{2}{|c|}{$\mathrm{Q}_{\text {ave }}$} & \multicolumn{2}{|c|}{$\mathrm{Q}_{7}$} \\
\hline & $\overline{\mathrm{R}_{\mathrm{p}}}$ & $P$-value* & $\mathrm{R}_{\mathrm{p}}$ & $P$-value* \\
\hline Castelo & -0.65 & 0.16 & 0.35 & 0.50 \\
\hline Fazenda Cacheta & -0.46 & 0.36 & 0.59 & 0.22 \\
\hline Fazenda Laginha & -0.40 & 0.43 & -0.45 & 0.37 \\
\hline Ibitirama & 0.09 & 0.87 & -0.31 & 0.54 \\
\hline Itaici & -0.76 & 0.08 & -0.01 & 0.99 \\
\hline Iúna & -0.68 & 0.14 & -0.08 & 0.88 \\
\hline Rive & -0.90 & 0.02 & 0.82 & 0.05 \\
\hline Terra Corrida & -0.58 & 0.23 & 0.00 & 1.00 \\
\hline Usina Fortaleza & -0.68 & 0.14 & -0.43 & 0.40 \\
\hline Usina Paineiras & -0.89 & 0.02 & 0.93 & 0.01 \\
\hline Usina São Miguel & -0.77 & 0.08 & 0.59 & 0.22 \\
\hline
\end{tabular}

Table 4 - Multiple linear equations representing the association of streamflow with forest coverage (FC, in \%) and annual rainfall $(\mathrm{Pa}$, in $\mathrm{mm})$ for the watersheds where correlation was statistically significant.

Tabela 4 - Equações de regressão linear múltipla para a associação das vazões com o percentual de cobertura florestal (FC, em \%) e com a precipitação total anual (Pa, em mm) nas sub-bacias para as quais a correlaçãofoi estatisticamente significativa.

\begin{tabular}{|c|c|c|c|c|}
\hline \multirow[t]{2}{*}{ Watershed } & \multirow[t]{2}{*}{ Adjusted equation } & \multirow[t]{2}{*}{$\mathrm{R}^{2}$} & \multicolumn{2}{|c|}{$P$-value* } \\
\hline & & & FC & $\mathrm{Pa}$ \\
\hline \multicolumn{5}{|c|}{ Average annual flow $\left(Q_{\text {ave }}\right)$ in $\mathrm{m}^{3} \mathrm{~s}^{-1}$} \\
\hline Rive (RIV) & $\mathrm{Q}_{\mathrm{ave}}=44.74-2.37 \mathrm{FC}+0.03 \mathrm{~Pa}$ & 0.94 & 0.02 & 0.01 \\
\hline Usina Paineiras (UPA) & $\mathrm{Q}_{\text {ave }}=-11.30-2.12 \mathrm{FC}+0.11 \mathrm{~Pa}$ & 0.97 & 0.02 & 0.01 \\
\hline \multicolumn{5}{|c|}{ Average minimum flow with seven days of duration $\left(\mathrm{Q}_{7}\right)$ in $\mathrm{m}^{3} \mathrm{~s}^{-1}$} \\
\hline Rive (RIV) & $\mathrm{Q}_{7}=-36.07+1.30 \mathrm{FC}+0.01 \mathrm{~Pa}$ & 0.74 & 0.05 & 0.05 \\
\hline Usina Paineiras (UPA) & $\mathrm{Q}_{7}=-85.86+2.91 \mathrm{FC}+0.03 \mathrm{~Pa}$ & 0.87 & 0.01 & 0.14 \\
\hline
\end{tabular}

Values equal to or below 0.05 are significant by the Student's t-test.

The watersheds that presented the highest percentages of forest on average were the IBI watershed (33\%), located in the area of Caparáo and covering part of the PARNA, in addition to those located in the Castelo river basin: FLA (42\%), USM (37\%) and CAS (34\%). Similar to the present study, another study (COUTINHO and SAMPAIO, 2007) also found greater presence of the forest in the PARNA region of Caparaó, in the municipalities of Conceição do Castelo, Vargem Alta, Castelo and Cachoeiro de Itapemirim (all partially or totally inserted in the Castelo river basin).

\subsection{Relationship of the streamflow with forest coverage and precipitation}

Table 3 shows that there was no direct relationship between streamflow and forest coverage for most watersheds, corroborating the assertion that streamflow responses to changes in the vegetation tend to be

Revista Árvore. 2018;42(2):e420204 very variable and often impossible to predict (Bosch and Hewlett, 1982)).

The association of forest coverage percentage with $Q_{\text {ave }}$ when the Pa effect is fixed was only significant for two watersheds (RIV and UPA). The negative values of the partial correlation coefficient (Table 3 ) in these two watersheds indicate an increasing $Q_{\text {ave }}$ trend in response to the reduced forest coverage percentage, and is similar to other studies in several regions of the planet (Bosch and Hewlett, 1982; Andréassian, 2004; Farley et al., 2005; Balbinot et al., 2008; Zhang et al., 2008; Locatelli and Vignola, 2009; Coe et al., 2011). As these two watersheds are the largest in the IRB, there is occurrence of all the previously mentioned forest formations, with a predominance of Ombrophilous Dense Forest (low slope, montane, and high montane) among higher regions, and Semi-deciduous Seasonal 
Forest (low lands and low slope) among lower altitude regions.

Some studies indicate the need for a minimum change in forest coverage in order to show variations in streamflow. These minimum values vary between $20 \%$ and $33 \%$ of the increase or suppression of forest coverage (Bosch and Hewlett, 1982; Johnson, 1998; Bruijnzeel, 2004). On the other hand, some studies report that even larger changes in forest coverage (greater than $33 \%$ ) may not cause changes to the streamflow regime. For example, no flow variation trends were observed (Trancoso et al., 2007) in large watersheds distributed in the Madeira, Tapajós and Xingu rivers watersheds, or even in those where more than half of the area is deforested (Trancoso et al., 2009). These data seem to indicate that changes in the FC alone may not be sufficient to affect the streamflow, although other factors also influence the hydrological behavior of watersheds. In the present study, neither of the two watersheds where the influence of FC on streamflow was verified presented an average percentage of changes in forest coverage (deforestation or reforestation) greater than $20 \%$. Considering the analyzed periods, these average percentages were $8.5 \%$ for the RIV and $9.3 \%$ for UPA, respectively.

The literature also indicates that changes in soil use have a more significant influence on the streamflow of watersheds, with an area smaller than 100 ha (significantly smaller size than the watersheds of the present study). This is partly because most studies conducted on the influence of land use changes associated with streamflow changes refer to small basins/ watersheds, which present a greater control of events and actions, as well as greater pedological, geomorphological and climatic homogeneitiess (Bruijnzeel, 2004). However, this does not exclude the possibility that changes in the FC can influence the streamflow of watersheds of any size; but this fact is less frequent in larger basins (Costa et al., 2003). In the present study, the changes in soil use (changes in FC) significantly influenced the streamflow of the two largest watersheds (RIV and UPA). This fact only reinforces the previous assertion that other factors also influence the hydrological behavior of watersheds, and not just FC or watershed area.

It should be noted that $\mathrm{Q}_{\mathrm{ave}}$ variations in RIV and UPA were not only caused by the variation in forest coverage percentage. The variation of Pa significantly influenced the flow of these two watersheds, as observed according to the parameters ( $p$-value) of the adjusted multiple linear regression equations (Table 4).

The influence of forests on the components of the hydrological cycle impacting on the streamflow, and consequently on the water availability of the watersheds has been well documented and systematized in the scientific literature ((Andréassian, 2004; Bruijnzeel, 2004; Calder, 2007; Oudin et al., 2008; Peel, 2009; Salemi et al., 2013; Ponette-González et al., 2014). As a rule, forests have the positive impact of increasing soil water infiltration, with consequent reduction of surface runoff and water erosion, which are also associated to higher re-supply of the aquifers and greater sub-surface flow. On the other hand, the increase of forest coverage is also usually associated with the increase of evapotranspiration (ET) and interception of precipitation by the canopy. The final impact of forests on the streamflow of watercourses depends on the balance between positive impacts of increased infiltration and negative impacts of increased ET and interception. In other words, when the infiltration increase is higher than the ET increase, there will be a tendency for the streamflow to increase. Still, if the increase in the ET is greater than the increase in infiltration, the impact on the streamflow will obviously be towards reducing it (Andréassian, 2004; Bruijnzeel, 2004; Cardoso et al., 2006). Due to different watersheds having totally different characteristics from one another regardless of how close they are, they will have different impacts on the streamflow resulting from changes in their forest coverage. Therefore, the impact of forests on the streamflow depend (to a greater or lesser extent) on several factors such as: the size of the watershed; the use of the soil being replaced by the forest; the fraction of the replaced area; the management, soil types and their properties (essentially their infiltration, transmission and water retention capacities); the depth of the water table; the spatial conformation of land uses in the river basin; climatic and meteorological characteristics prevailing in the region; climate changes; the topography of the land and other morphometric characteristics of the watershed (Farley et al., 2005; Oudin et al., 2008; Peel, 2009; Komatsu et al., 2010; Williams et al., 2012; Ferraz et al., 2013; Salemi et al., 2013). Based on the abovementioned for the present study, most of the nonsignificant results found may be due to a balance between variations in infiltration and ET variations, resulting in little influence of the forests on the streamflow. 
In relation to the $\mathrm{Q}_{7}$, it was observed that only the streamflows of RIV and UPA watersheds were altered due to the variation in the forest coverage percentage when the effects of $\mathrm{Pa}$ were fixed (Table 3 ). According to the partial correlation analysis, the relationship between forest coverage and $\mathrm{Q}_{7}$ showed a positive trend, indicating that the forest contributed to an increase in the minimum streamflow, as also evidenced in other watersheds (Chandler, 2006; Locatelli and Vignola, 2009; Ogden et al., 2013; Smethurst et al., 2015). In forested watersheds, subsurface hydrologic processes (infiltration and water storage in the soil profile) are favored by feeding the base stream (Bruijnzeel, 2004)). Forests located in the higher regions are particularly important, as they ensure better soil water infiltration conditions, and consequently greater re-supply to the aquifers, reflecting in greater drought streamflow in the lower parts of the basins. In this sense, the FC of the watersheds located upriver (FLA, IBI, IUN and UFO) may have fundamentally contributed to the increase of $\mathrm{Q}_{7}$ downriver (RIV and UPA). Of these four watersheds (as shown in Table 2), the FC increased in three (FLA, IBI and UFO) and remained practically constant in one (IUN).

In addition to the forest percentage, the Pa variable also had significant participation in the increase of $\mathrm{Q}_{7}$ in the RIV watershed, as seen from the result ( $p$ value) of the multiple regression analysis (Table 4 ). However, such a trend was not observed in the UPA watershed, since $\mathrm{Pa}$ was not significant in this relationship (Table 4).

In some cases forests in the IRB tend to reduce $Q_{\text {ave }}$ due to increased evapotranspiration. This effect is in principle deleterious, but is partially offset by the increase in minimum streamflow, represented by the $\mathrm{Q}_{7}$.

\section{CONCLUSIONS}

The present study was able to identify associations between the forest coverage percentage and $\mathrm{Q}_{\text {ave }}$ and $\mathrm{Q}_{7}$ in the Rive and Usina Paineiras watersheds, with outlet located in the lowest lands of IRB. Thus, we found that the increase in the forest resulted in a reduction in the average streamflow in the Rive and Usina Paineiras watersheds when the precipitation effect is fixed, in contrast to an increase in the minimum flow with seven days of duration.

Revista Árvore. 2018;42(2):e420204

\section{ACKNOWLEDGEMENTS}

To the National Council of Scientific and Technological Development - CNPq (process 304916/ 2017-0) and to the Foundation for Support to Research and Innovation of Espírito Santo State (Fundação de Amparo à Pesquisa e Inovação do Espírito Santo FAPES) for the financial support (processes 66690528 and 80709583/18).

\section{REFERENCES}

Alvares CA, Stape JL, Sentelhas PC, Gonçalves JLM, Sparovek G. Köppen's climate classification map for Brazil. Meteorologische Zeitschrift. 2013;22(6):711-28.

Andréassian V. Waters and forests: From historical controversy to scientific debate. Journal of Hydrology. 2004;291(1-2):1-27.

Bacellar LAP. O papel das florestas no regime hidrológico de bacias hidrográficas. Geografia Brasileira. 2005;1(1):1-39.

Balbinot R, Oliveira NK, Vanzetto SC, Pedroso K, Valerio AF. O papel da floresta no ciclo hidrológico em bacias hidrográficas. Ambiência. 2008;4(1):131-49.

Böhmelt T, Bernauer T, Buhaug H, Gleditsch NP, Tribaldos T, Wischnath G. Demand, supply, and restraint: Determinants of domestic water conflict and cooperation. Global Environmental Change. 2014;29:337-48.

Bosch JM, Hewlett JD. A review of catchment experiments to determine the effect of vegetation changes on water yield and evapotranspiration. Journal of Hydrology. 1982;55(1-4):3-23.

Brito SL, Pereira TTC, Martins IC. Sediments of watersheds from Frutal and Bebedouro Streams (Frutal, MG, Brazil) as an indicator of human activities. Ambiente e Agua - An Interdisciplinary Journal of Applied Science. 2016;12:1-17.

Brown AE, Western AW, McMahon TA, Zhang L. Impact of forest cover changes on annual streamflow and flow duration curves. Journal of Hydrology. 2013;483:39-50.

Bruijnzeel LA. Hydrological functions of tropical 
forests: Not seeing the soil for the trees? Agriculture, Ecosystems and Environment. 2004;104(1):185-228.

Calder IR. Forests and water - Ensuring forest benefits outweigh water costs. Forest Ecology and Management. 2007;251(1-2):110-20.

Cardoso CA, Dias HCT, Martins SV, Soares CPB. Caracterização hidroambiental da bacia hidrográfica do rio Debossan, Nova Friburgo, RJ. Revista Árvore. 2006;30(2):249-56.

Chandler DG. Reversibility of forest conversion impacts on water budgets in tropical karst terrain. Forest Ecology and Management. 2006;224(1-2):95103.

Coe MT, Latrubesse EM, Ferreira ME, Amsler ML. The effects of deforestation and climate variability on the streamflow of the Araguaia River, Brazil. Biogeochemistry. 2011;105(1):119-31.

Costa MH, Botta A, Cardille JA. Effects of largescale changes in land cover on the discharge of the Tocantins River, Southeastern Amazonia. Journal of Hydrology. 2003;283(1-4):206-17.

Coutinho LM, Sampaio TVM. Evolução da supressão de florestas na Bacia Hidrográfica do Rio Itapemirim via uso de imagens orbitais. Revista Camiliana de Iniciação Científica. 2007;2:156-63.

Farley KA, Jobbágy EG, Jackson RB. Effects of afforestation on water yield: A global synthesis with implications for policy. Global Change Biology. 2005;11(10):1565-76.

Ferraz SFB, Lima WP, Rodrigues CB. Managing forest plantation landscapes for water conservation. Forest Ecology and Management. 2013;301:58-66.

Foody GM. Thematic map comparison. Photogrammetric Engineering \& Remote Sensing. 2004;70(5):627-33.

Fundação SOS Mata Atlântica. Atlas dos remanescentes florestais da Mata Atlântica, período 2013-2014. [s.l: s.n.]. Disponível em: http:// www.sosmatatlantica.org.br.

Gleick PH. Water, drought, climate change, and conflict in Syria. Weather, Climate, and Society. 2014;6(3):331-40.

Hoekstra AY, Mekonnen MM, Chapagain AK, Mathews RE, Richter BD. Global monthly water scarcity: Blue water footprints versus blue water availability. PLoS ONE. 2012;7(2):e32688.

Hornbeck JW, Adams MB, Corbett ES, Verry ES, Lynch JA. Long-term impacts of forest treatments on water yield: a summary for northeastern USA. Journal of Hydrology. 1993;150(2-4):323-44.

Instituto Brasileiro de Geografia e Estatística IBGE. Manual técnico da vegetação brasileira. $2^{a}$.ed. Rio de Janeiro: 2012.

Instituto Estadual de Meio Ambiente e Recursos Hídricos - IEMA. Ortofotomosaicos 2007/2008. Escala 1:35.000, resolução espacial de $1 \mathrm{~m}$, georeferenciado no Sistema de Projeção UTM, Datum WGS 84, Zona 24S. Vitória: 2008.

Johnson R. The forest cycle and low river flows: a review of UK and international studies. Forest Ecology and Management. 1998;109(1-3):1-7.

Komatsu H, Kume T, Shinohara Y, Miyazawa Y, Otsuki K. Did annual run-off and low flow decrease with reduced forestry practices in Japan? Hydrological Processes. 2010;24(17):2440-51.

Locatelli B, Vignola R. Managing watershed services of tropical forests and plantations: Can meta-analyses help? Forest Ecology and Management. 2009;258(9):1864-70.

Mendes NGS. Estudo das vazões na Bacia Hidrográfica do Rio Itapemirim. [s.1.] Universidade Federal do Espírito Santo; 2016.

Ogden FL, Crouch TD, Stallard RF, Hall JS. Effect of land cover and use on dry season river runoff, runoff efficiency, and peak storm runoff in the seasonal tropics of Central Panama. Water Resources Research. 2013;49(12):8443-62.

Oudin L, Andréassian V, Lerat J, Michel C. Has land cover a significant impact on mean annual streamflow? An international assessment using 1508 catchments. Journal of Hydrology. 2008;357(3-4):303-16. 
Peel MC. Hydrology: catchment vegetation and runoff. Progress in Physical Geography. 2009;33(6):837-44.

Ponette-González AG, Marín-Spiotta E, Brauman KA, Farley KA, Weathers KC, Young KR. Hydrologic connectivity in the high-elevation tropics: Heterogeneous responses to land change. BioScience. 2014;64(2):92-104.

Rosa FS, Tonello KC, Valente ROA, Lourenço RW. Estrutura da paisagem, relevo e hidrografia de uma microbacia como suporte a um programa de pagamento por serviços ambientais relacionados à água. Ambiente e Agua - An Interdisciplinary Journal of Applied Science. 2014;9(3):526-39

Rosa FS, Tonello KC, Lourenço RW. Selection of priority areas for payment of environmental services: an analysis at the watershed level. Ambiente e Agua - An Interdisciplinary. Journal of Applied Science. 2016;11(2):448-61

Salemi LF, Groppo JD, Trevisan R, Moraes JM, Ferraz SFB, Villani JP. et al. Land-use change in the Atlantic rainforest region: Consequences for the hydrology of small catchments. Journal of Hydrology. 2013;499:100-9.

Schewe J, Heinke J, Gerten D, Haddeland I, Arnell NW, Clark DB. et al. Multimodel assessment of water scarcity under climate change. Proceedings of the National Academy of Sciences. 2014;111(9):3245-50.

Smethurst PJ, Almeida AC, Loos RA. Stream flow unaffected by Eucalyptus plantation harvesting implicates water use by the native forest streamside reserve. Journal of Hydrology: Regional Studies. 2015;3:187-98.

Trancoso R, Carneiro Filho A, Tomasella J, Schietti J, Miller BRF, Pritchard R. Deforestation and conservation in major watersheds of the Brazilian Amazon. Environmental Conservation. 2009;36(4):277-88.

Trancoso R, Carneiro Filho A, Tomasella J. Amazônia, desflorestamento e água: A interação entre a floresta tropical e a maior bacia hidrográfica do planeta. Ciência Hoje. 2007;40(239):30-7.

Williams CA, Reichstein M, Buchmann N, Baldocchi D, Beer C, Schwalm C. Climate and vegetation controls on the surface water balance: Synthesis of evapotranspiration measured across a global network of flux towers. Water Resources Research. 2012;48:1-13.

Zhang X, Zhang L, Zhao J, Rustomji P, Hairsine P Responses of streamflow to changes in climate and land use/cover in the Loess Plateau, China. Water Resources Research. 2008;44(7):1-12. 